\title{
NOVEL BREADS FORTIFIED THROUGH OILSEED AND NUT CAKES
}

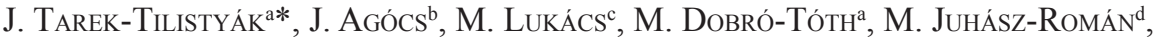 \\ Z. DINYA ${ }^{a}$, J. JEKÖ ${ }^{\mathrm{a}}$, AND E. MÁTHÉa,e \\ a University College of Nyíregyháza, H-4400 Nyíregyháza, Sóstói út 31/b. Hungary \\ ${ }^{\mathrm{b}}$ ABOMILL Ltd., H-4400 Nyíregyháza, Simai út 6. Hungary \\ ${ }^{\mathrm{c}}$ Közép-tiszai Agricultural Ltd., H-5340 Kunhegyes, Szabadság tér 9-10. Hungary \\ d Corvinus University of Budapest, H-1118 Budapest, Somlói út 12-16. Hungary \\ e "Vasile Goldis" Western University of Aradi 310414, Arad, L. Rebreanu str. 91-93. Romania
}

(Received: 14 February 2013; accepted: 19 April 2013)

\begin{abstract}
The nutritive value, the microbiological safety of oilseed cake (OSC) obtained from naked pumpkin seed (PuC), sunflower seed (SC), yellow linseed (LC), and walnut (WnC), and their impact on wheat flour (WF) dough and bread sensory characteristics at $5 \%$ and $10 \%$ addition ratio were investigated. The OSCs had high protein $(34-50 \%)$, fat $(8-15 \%)$, total dietary fibre (23-36\%) content and high energy value (383-444 kcal/100 g)). The OSC samples with a minimal exception fulfilled the requirements of feed legislation in force. An increased water absorption, dough development time, and reduced elasticity were observed probably due to the enhanced fiber and protein content. Dough stability increased with $\mathrm{WnC}$, and decreased with $\mathrm{PuC}$ or SC addition. Enrichment provided the appearance of a brown bread for $\mathrm{WnC}$, of a half-brown bread for LC. PuC gave an unusual look. The appearance of OSC fortified bread similar to daily bread, was an advantage resulting the $1^{\text {st }}$ rank for $10 \% \mathrm{WnC}$ bread and the $2^{\text {nd }}$ one for $10 \% \mathrm{LC}$ bread $(\mathrm{P}=0.05)$. The studied OSCs are suitable for food enrichment, however, in case of PuC and SC fortified flour blends, hydrocolloid application is recommended. Our data suggest that the newly developed fortified breads could be a valuable source for healthy nutrition.
\end{abstract}

Keywords: walnut, pumpkin seed, sunflower seed, linseed, expeller, dough, bread, enrichment

Fortified breads offer health benefits by the bioactive food components: e.g. dietary fibers (DFs) and unsaturated fatty acids. Brans are sources of DFs and applied for enrichment of bakeries, however brans still bear food safety hazard by their potential mycotoxin contamination (VIDAL et al., 2013). Vegetable oils are sources of unsaturated fatty acids but applied in margarins. The food industry is always seeking new cost-effective functional ingredients that impart desirable properties to a range of manufactured food products (DAY et al., 2006). Recently, consumers refuse the foods containing artificial additives, especially bread (KIm et al., 2006). Oilseed cake, the by-product of oil pressing, can offer solution for these industrial and consumer demands. OSCs in meat batters are reported using bambara groundnut seed flour (Alakali et al., 2010) and walnut meal (COFRADES et al., 2008). Differently processed oilseed flours, e.g. solvent extracted OSCs, protein concentrates, and isolates applied in composite flours, are studied for decades. Emerging interest shows toward the characterization and utilization of the oil rich pressing residues.

\footnotetext{
* To whom correspondence should be addressed. Phone: +36302420247; fax: +3630599478; e-mail: judit.tilistyak@gmail.com
} 
The objective of our research was to design new fortified bread using OSCs. We studied the macro-composition of OSCs, their microbiological safety, their effect on the rheological properties of WF dough, the impact on sensory attributes of breads, and customers' perception. We have shown that the OSC fortified breads can be new and alternative choices for healthconscious consumers.

\subsection{Materials}

\section{Materials and methods}

Milled, pressing residues of yellow linseed, naked pumpkin seed, and hulled sunflower seed were purchased from Közép-tiszai Agricultural Ltd. The partical size was $94 \%$ of $0.25-0.5$ $\mathrm{mm}$. Walnut cake samples were gift from Tarpai Manufaktúra Co., and milled in laboratory then passed through a sieve with appertures of $500 \mu \mathrm{m}$. Wheat flour (WF-C1; WF-C2; ash: $0.8 \%$ ) were from ABOMILL Ltd. The OSCs and WF samples were collected from different batches. The OSCs were packed in opaque plastic bags, and stored at $4{ }^{\circ} \mathrm{C}$ for further experiments. Ingredients used for breadmaking were purchased from the local market. The chemical reagents were of analytical grade from VWR International.

\subsection{Determination of macronutrient composition and energy density}

Moisture was determined with drying by air oven method at $103{ }^{\circ} \mathrm{C}$ to constant weight. Protein was calculated as $\mathrm{N}$ content $\times 6.25$, to which nitrogen content was determined by Elementar Rapid N cube analyzer through quantitative combustion digestion at $900{ }^{\circ} \mathrm{C}$ in excess oxygen. Total fat content was determined by Soxtec Avanti 2055 Manual System instrument according to the MSZ EN ISO (2000). Total dietary fiber was determined by Megazyme Total Dietary Fibre Assay Procedure Kit (Noack Group). Ash was determined in electric furnace after 8 -h ashing at $550{ }^{\circ} \mathrm{C}$. Total carbohydrate content was calculated as the difference between 100 and the sum of the percentage of moisture, protein, total fat, and ash. Energy was calculated from the percentage of protein, total carbohydrates, and total fat. The conversion factors were $4.0 \mathrm{kcal} \mathrm{g}^{-1}$ for protein and for carbohydrates and $9.0 \mathrm{kcal} \mathrm{g}^{-1}$ for fat.

\subsection{Microbiological examinations}

The microbiological analysis included the enumeration of total mesophilic aerobic microbial count (TAMC) according to ISO (2003), the mould number according to the ISO (1999). Coliform bacteria and E. coli were determined on ChromoCULT ${ }^{\circledR}$ Coliform agar (Merck) after 24-hour incubation at $37^{\circ} \mathrm{C}$.

\subsection{Evaluation of dough properties}

Rheological measurements were carried out with composite flours consisting of WF and different OSC (5\% or 10\%) using valorigraph (LABORMIM PQA 205, Hungary) instrument according to MSZ (1988). WF alone (100\%) was the control.

\subsection{Baking trial}

Breads were prepared in a factory as follows: a great volume of dough was prepared using $8 \mathrm{~kg}$ wheat flour, $2 \%$ salt, $1.5 \%$ dry yeast, $1 \%$ "Hungepan" dough powder, and 4.21 tapwater. Twelve min kneading was followed by dividing the dough into 11 parts. Into a portion $5 \%$ 
and $10 \%$ of different OSCs were introduced. The same ratio of WF was added to the control dough. To reach the desired texture of each portion uniformly, tapwater complementation was applied simultaneously during a further 10-min kneading. The resulting dough was leavened at $28^{\circ} \mathrm{C}$ for $25 \mathrm{~min}$. Then the dough was punched down, bisected, and fermented in dough-basket for further $45 \mathrm{~min}$ at $30{ }^{\circ} \mathrm{C}$ and $85 \% \mathrm{RH}$. Round loaves were baked without bread pan at $230^{\circ} \mathrm{C}$ for $35 \mathrm{~min}$ in gas oven.

\subsection{Evaluation of sensory attributes of breads}

The baked loaves were evaluated after cooling to room temperature. Descriptive characterizations of enriched breads regarding appearance, colour, scent, texture, flavour, and rank test regarding overall acceptability were performed. The sensory panel consisted of 10 judges.

\subsection{Statistical analysis}

The measurements were performed in duplicate. Two values were averaged into one replicate. Data obtained from the rank test of sensory analysis were evaluated according to KRAMER (1956). In case of 10 judges and 9 treatments, rank total, as the sum of the ordinal numbers per treatment, 31-69 is required for significance at the 1\% level, and 35-65 at the 5\% level. Rank total must be lower than $1^{\text {st }}$ value or higher than $2^{\text {nd }}$ value to indicate significance.

\section{Results and discussion}

\subsection{Macronutrient composition and energy density of OSCs}

The results of the chemical analysis are shown in Table 1. The moisture content of OSCs was low, principally for $\mathrm{WnC}$, not exceeding the value recommended for long-time storage of full-fat seeds, which is $8-12 \%$ for walnut (EC, 2001) and $8-9 \%$ for linseed, sunflower seed, and pumpkin seed. The protein content of OSCs was also high (34-50\%) and comparable with the corresponding data of plant origin protein sources as reported $41 \%$ for full-fat soya, $21.7-26 \%$ for dry legumes (beans, peas, and lentil) by RodLer (2008) with the contrast that the OSCs are not normally consumed as food itself. The fat content was at the expected value $(\sim 10 \%)$ for PuC and SC, and higher for WnC. Regarding the ash content, brans only approach that high ash value as measured for OSCs. Of the carbohydrate content, dietary fiber

Table 1. Macronutrient* compositon and energy density** of different oilseed cakes

\begin{tabular}{lcccccccc}
\hline $\begin{array}{l}\text { Type of } \\
\text { OSC }\end{array}$ & Moisture & Protein & Fat & Ash & TCH & TDF & SF & $\begin{array}{c}\text { Energy } \\
\text { density }\end{array}$ \\
\hline WnC & $3.6 \pm 0.3$ & $39.4 \pm 0.5$ & $15.5 \pm 0.2$ & $4.9 \pm 0.8$ & $36.6 \pm 1.8$ & $36.6 \pm 0.5$ & n.d. & 444 \\
LC & $7.4 \pm 0.2$ & $34.5 \pm 0.2$ & $14.3 \pm 0.4$ & $5.4 \pm 0.2$ & $38.4 \pm 1.0$ & $32.4 \pm 0.3$ & $17.6 \pm 0.3$ & 420 \\
PuC & $7.2 \pm 0.2$ & $50.4 \pm 0.5$ & $8.2 \pm 0.3$ & $7.2 \pm 0.3$ & $27.0 \pm 1.3$ & $23.2 \pm 0.5$ & $16.2 \pm 0.2$ & 383 \\
SC & $7.6 \pm 0.4$ & $48.5 \pm 0.4$ & $9.1 \pm 0.5$ & $7.0 \pm 0.1$ & $27.8 \pm 1.4$ & $24.9 \pm 0.6$ & $20.7 \pm 0.2$ & 387 \\
\hline
\end{tabular}

*: (\%); **: (kcal/100g); n.d.: not determined; TCH: total carbohydrates; TDF: total dietary fiber; SF: soluble fibre 
represented the most part. The TDF values of OSCs were comparable with wheat and cornbran (43\%) or rice bran (27\%) (ABDUL-HAMID \& LUAN, 2000). The TDF/TCH ratio suggests low sugar (mono, di-saccharide) content, which is a prerequisite for the development of healthy food.

\subsection{Microbiological contamination of OSCS}

Results of microbiological examinations are summarized in Table 2 and evaluated in accordance with Codex Pabularis Hungaricus (as feed) and Hungarian Health Ministry regulation No 4/1998 (as food) comparing to brans, as food industrial by-product, due to the lack of official categorization of OSC. Prerequisite of nutritional application is being free from Salmonella, which can be presupposed by the results of E. coli determination.

Table 2. Microbiological contamination* of OSCs after production

\begin{tabular}{lcccc}
\hline Type of OSC & TAMC & Moulds & Coliforms & E.coli \\
\hline Walnut cake & $6.6 \times 10^{2}$ & $3.3 \times 10^{1}$ & $<10$ & $<10$ \\
& $4.0 \times 10^{2}$ & $1.5 \times 10^{2}$ & $<10$ & $<10$ \\
\hline Linseed cake & $6.4 \times 10^{3}$ & $1.0 \times 10^{2}$ & $4.4 \times 10^{3}$ & $<10$ \\
\hline Pumpkin seed cake & $1.5 \times 10^{4}$ & $1.1 \times 10^{4}$ & $<10$ & $<10$ \\
& $1.7 \times 10^{3}$ & $2.0 \times 10^{2}$ & $<10$ \\
\hline Sunflower seed cake & $3.5 \times 10^{3}$ & $2.3 \times 10^{2}$ & $7.0 \times 10^{2}$ & $<10$ \\
& $3.0 \times 10^{3}$ & $<10$ & $<10$ & $<10$ \\
\hline
\end{tabular}

*: data are given in $\mathrm{CFU} \mathrm{g}^{-1}$.

The TAMC was quite low for each sample, way below the $10^{6} \mathrm{CFU} \mathrm{g}^{-1}$ threshold stated for feeds. The level of mould contamination was tolerable in the range of $<10^{1}-4.7 \times 10^{2}$ $\mathrm{CFU} \mathrm{g}{ }^{-1}$ for the vast majority of the samples, falling short of the $10^{3} \mathrm{CFU} \mathrm{g}^{-1}$ limit laid down for brans. Based on the results of coliform detection, the vast majority of OSC samples were compliant comparing to the $10^{3} \mathrm{CFU} \mathrm{g}^{-1}$ limit laid down for Enterobacteriaceae in feed materials and in bran. The OSCs with minimal exception complied with the feed legislation in force. For food application these statements are conditional. In flour blends, the microbiological contamination of OSC origin is diluted decreasing the risk of deterioration of food quality.

\subsection{Effect of OSC incorporation on dough mixing properties}

The control WFs obtained from different batches had different quality. The addition of OSCs to WF brought significant changes into the dough mixing behavior (Table 3). 
Table 3. Effect of oilseed cake addition on valorigraph characteristics of wheat flour*

\begin{tabular}{|c|c|c|c|c|c|}
\hline Dough formulation & WA $(\%)$ & DDT (min) & $\mathrm{ST}(\min )$ & EL (VU) & SF (VU) \\
\hline$W F-C 1$ & 57.6 & 3.4 & 1.6 & 140 & 95 \\
\hline $\mathrm{WF}-\mathrm{Cl}$ and $\mathrm{WnC}(5)$ & 58.0 & 5.2 & 2.0 & 130 & 70 \\
\hline $\mathrm{WF}-\mathrm{C} 1$ and $\mathrm{WnC}(10)$ & 59.0 & 9.0 & 2.3 & 120 & 25 \\
\hline $\mathrm{WF}-C 1$ and $\mathrm{LC}(5)$ & 60.0 & 4.8 & 1.5 & 110 & 90 \\
\hline WF- $C 1$ and $\mathrm{LC}(10)$ & 64.0 & 5.5 & 1.0 & 75 & 100 \\
\hline$W F-C 2$ & 62.0 & 5.3 & 2.0 & 150 & 65 \\
\hline $\mathrm{WF}-\mathrm{C} 2$ and $\mathrm{PuC}(5)$ & 63.6 & 5.3 & 1.0 & 140 & 80 \\
\hline WF-C2 and PuC(10) & 64.4 & 7.5 & 0.0 & 120 & 80 \\
\hline $\mathrm{WF}-\mathrm{C} 2$ and $\mathrm{SC}(5)$ & 63.0 & 5.0 & 0.5 & 140 & 155 \\
\hline $\mathrm{WF}-C 2$ and $\mathrm{SC}(10)$ & 64.0 & 4.5 & 0.0 & 130 & 170 \\
\hline
\end{tabular}

*:N=4 per each blend or control. Number in parentheses means the ratio of OSC complemented to wheat flour. WA: water absorption; DDT: dough development time; ST: dough stability; EL: elasticity; SF: degree of softening

OSC addition significantly increased the WA of composite flours with the exception of $5 \% \mathrm{SC}$ and $5 \% \mathrm{WnC}$, due to the higher protein and dietary fiber contents of the blends, which can contribute to an enhanced dough yield and productivity. DDT was significantly increased with $\mathrm{WnC}$, LC, and $10 \% \mathrm{PuC}$ addition, suggesting the competition of OSC and WF constituents for water in the dough system, resulting in a longer kneading period in practice. An increasing stability was observed for $\mathrm{WnC}$ substitution making the dough harder, giving much resistance to mechanical mixing. This hardening effect might be the result of walnut particle entrapment within the gluten network structure as reported for lupine protein isolate and concentrate by GüEMES-VERA and co-workers (2004), and WnC has greater water holding capacity for retaining absorbed water. $\mathrm{PuC}$ and $\mathrm{SC}$ addition decreased the stability significantly, resulting poor machinability and deterioriated gluten network. The elasticity of each OSC/WF blends decreased, significantly in the case of $\mathrm{LC}$ or $10 \% \mathrm{PuC}$ addition. The substitution of gluten proteins by the non-gluten-forming vegetable proteins causes a dilution effect and consequently weakens the dough as discussed by PARASKEVOPOULOU and coworkers (2010).

\subsection{Sensory properties of OSC fortified breads, consumers 'perception}

OSC addition could result colourful bread with feasible flavour as a spectacular effect, which is a novelty in baking industry practice. Slices from the middle of the baked loaves are shown on Fig. 1. WnC fortified breads were brown, exceptional green colour was found for PuC added loaves, yellowish for LC, greyish-white or off-white for SC complementation. In our baking trial all the loaves opened, causing deformity and sloping, which could be explained with the underproduction (processed/optimal dough volume ratio), and the accuracy of the 
small enterprise doughmaking method applied (additional watering step to compose adequate dough consistency). PuC or SC addition caused the spreading of loaves, as also was observed for dough, which was an overmixed state, due to the mixing time applied uniformly. Our baking results of SC breads harmonize with that of EL-ADAWY (1997).

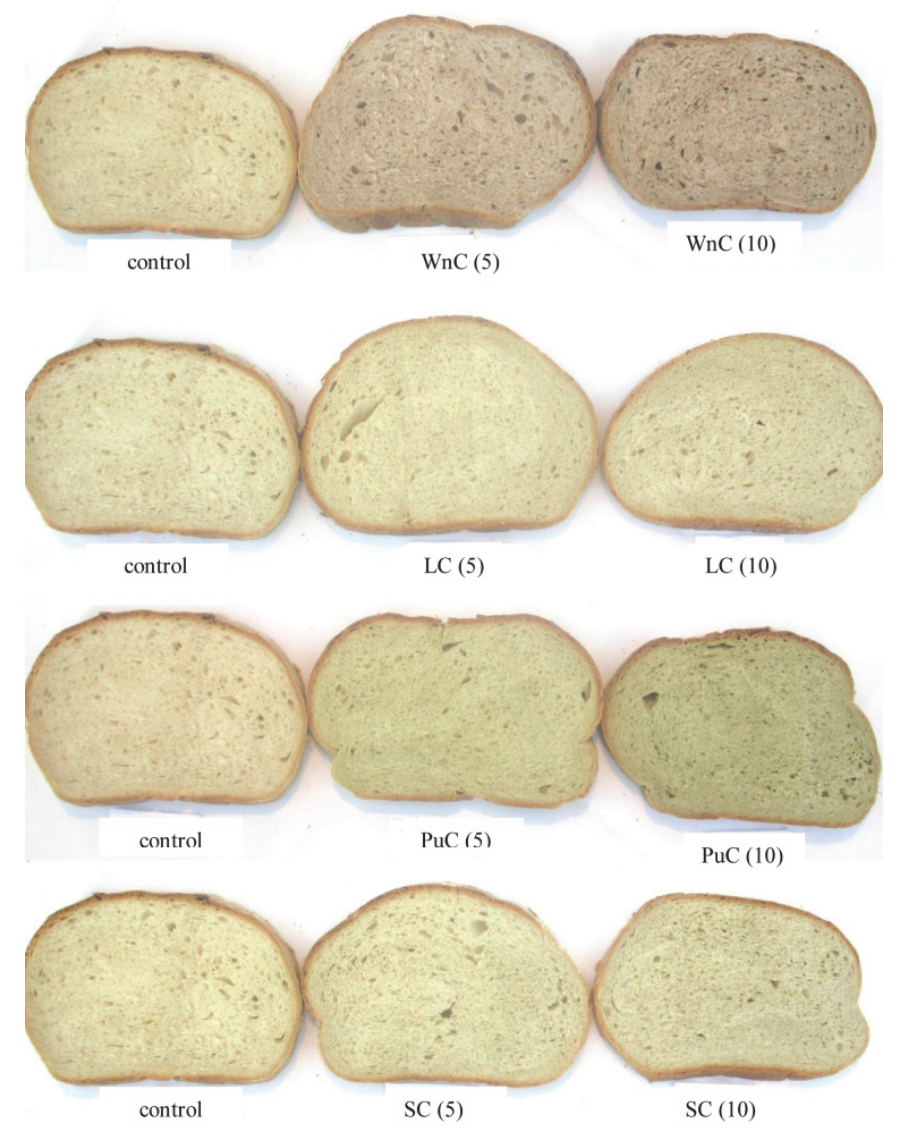

Fig. 1. Loaves fortified with different OSC at different complementing ratio* *control loaf (left), loaves with 5\% OSC addition (middle), loaves with $10 \%$ OSC addition (right)

Based on the outcome of rank test (Table 4), the treatments (breads) could be separated into 5 groups $(\mathrm{P}=0.05)$ as follows: the $\mathrm{WnC}(10)$ enriched bread was found the most palatable as ranked the first, the $\mathrm{LC}(10)$ was ranked the second. The 5\% SC enriched bread and the control one were the least plausible breads in decreasing order. The 5\% LC, $\mathrm{WnC}, \mathrm{PuC}, 10 \%$ $\mathrm{PuC}$, and SC fortified breads had the same acceptability and got to the third place. 
Table 4. Rank and rank total of OSC fortified breads

\begin{tabular}{|c|c|c|c|c|c|c|c|c|c|}
\hline \multirow{3}{*}{$\begin{array}{l}\text { Number of } \\
\text { judges }\end{array}$} & \multicolumn{9}{|c|}{ Type of treatments (fortified breads) } \\
\hline & \multirow[b]{2}{*}{ Control } & \multicolumn{4}{|c|}{$5 \%$ complementing ratio } & \multicolumn{4}{|c|}{$10 \%$ complementing ratio } \\
\hline & & $\mathrm{WnC}$ & $\mathrm{LC}$ & $\mathrm{PuC}$ & $\mathrm{SC}$ & $\mathrm{WnC}$ & LC & $\mathrm{PuC}$ & $\mathrm{SC}$ \\
\hline 1 & 3 & 7 & 1 & 4 & 8 & 2 & 5 & 9 & 6 \\
\hline 2 & 9 & 3 & 5 & 1 & 6 & 2 & 4 & 8 & 7 \\
\hline 3 & 9 & 4 & 3 & 8 & 6 & 1 & 2 & 7 & 5 \\
\hline 4 & 3 & 8 & 5 & 2 & 9 & 7 & 1 & 4 & 6 \\
\hline 5 & 5 & 2 & 6 & 8 & 4 & 1 & 3 & 9 & 7 \\
\hline 6 & 7 & 5 & 1 & 3 & 8 & 2 & 6 & 9 & 4 \\
\hline 7 & 9 & 5 & 4 & 6 & 8 & 3 & 2 & 7 & 1 \\
\hline 8 & 9 & 8 & 5 & 3 & 6 & 2 & 7 & 1 & 4 \\
\hline 9 & 9 & 7 & 5 & 6 & 8 & 1 & 2 & 3 & 4 \\
\hline 10 & 9 & 2 & 8 & 4 & 3 & 5 & 1 & 7 & 6 \\
\hline Rank total & $72^{a, b}$ & 51 & 43 & 45 & $66^{\mathrm{a}}$ & $26^{\mathrm{a}, \mathrm{b}}$ & $33^{\mathrm{a}}$ & 64 & 50 \\
\hline
\end{tabular}

letters mean significant differences: ${ }^{\mathrm{a}} \mathrm{P} \leq 0.05 ;{ }^{\mathrm{b}} \mathrm{P} \leq 0.01$

The predomination of $\mathrm{WnC}(10)$ bread can be explained by the similarity of appearance to the rye-bread, which is prevalent choice of the health-conscious consumers. In contrast to rye-bread, $\mathrm{WnC}(10)$ had more crumb softness, also walnut's flavor was described. It can give a luxury feeling even for those who consume rye-bread or cannot afford the walnut. The LC(10) bread showed similarity in appearance to the half-brown bread, which is a vendible product with a 63-67\% market share in Hungary (VARGA, 2010). The LC(10) bread had soft, slightly thicker texture, and fine, moderate linseed flavour. The LC(10) bread can be alternative for orientating the half-brown bread consumers to a healthier nutrition without spectacular alteration of bread consuming habits. The breads fortified with $5 \%$ of different OSCs also have got good $\operatorname{rank}\left(2^{\text {nd }}\right.$ at $\mathrm{P}=0.01,3^{\text {rd }}$ at $\left.\mathrm{P}=0.05\right)$, because the novelty, the specialty, and the functionality were also present in them. The $\mathrm{SC}(5)$ enriched bread relegated to the background, because the incorporation of SC turned the crumb colour to an unusual greyishwhite tinge. The positive change of flavour could not balance the adverse effect on colour. The last rank for control bread was partly due to the similar softness of fortified breads and their high number of total treatments.

\section{Conclusions}

The present study has demonstrated that the pressing residue of different oilseeds and walnut are promising materials from natural sources. Supplying OSCs in compliant microbiological quality, they can be applied in the field of new, healthier food development, such as value added breads with special characteristics in terms of aroma and flavour. WnC was found to be a remarkable, microbiologically safe material for nutrition, though requiring more time for 
doughmaking. With LC, the production yield can be enhanced, without adverse effects on breadmaking technology. PuC and SC incorporation showed detrimental effect on dough visco-elastic properties, therefore hydrocolloid replacement or hard-type WF is recommended for the production of $\mathrm{PuC}$ or SC fortified breads. OSC fortified bakeries can widen the assortment of functional foods.

The authors would like to thank the Hungarian Research and Development Agency for financial support of our research programs EA_KUTF_05-napraf05, EA_KUTF_05-gabona05.

\section{References}

Abdul-Hamid, A. \& Luan, S.Y. (2000): Functional properties of dietary fibre prepared from defatted rice bran. $F d$ Chem, 68, 15-19.

Alakali, J.S., Irtwange, S.V. \& Mzer, M.T. (2010): Quality evaluation of beef patties formulated with bambara groundnut seed flour. Meat Sci., 85, 215-223.

Cofrades, S., Serrano, A., Ayo, J., Carballo, J. \& Jiménez-Colcenero, F. (2008): Characteristics of meat batters with added native and preheated defatted walnut. Fd Chem., 107, 1506-1552.

Day, L., Augustin, M.A., Batey, I.L. \& Wrigley, C.W. (2006): Wheat gluten uses and industry needs. Trends Fd Sci Tech., 17, 82-90.

El-AdAwy, T.A. (1997): Effect of sesame seed protein supplementation on the nutritional, physical, chemical and sensory properites of wheat flour. Fd Chem., 59, 7-14.

EC (2001): Commission Regulation (European Commision) No 175/2001 laying down the marketing standard for walnuts in shell. $O J$. L 26, 27.1.2001. 24-30.

Güemes-Vera, N., Arciniega-Ruiz Esperza, O. \& Dávila-Ortiz, G. (2004): Structural analysis of the Lupinus mutabilis seed, its flour, concentrate and isolate as well as their behavior when mixed with wheat flour. $L W T$ Fd Sci. Tech.., 37, 283-290.

ISO (1999): Microbiology. General guidance for enumeration of yeasts and moulds. Colony count technique at 25 ${ }^{\circ} \mathrm{C}$. No. ISO 7954:1999

ISO (2003): Microbiology of food and animal feeding stuffs - Horizontal method for the enumeration of microorganisms - Colony-count technique at $30{ }^{\circ} \mathrm{C}$. No. ISO 4833:2003

Kim, J.H., MaEda, T. \& Morita, N. (2006): Effect of fungal $\alpha$-amylase on the dough properties and bread quality of wheat flour substituted with polished flours. Fd Res. Int., 39, 117-126.

Kramer, A. (1956): A quick, rank test for significance of differences in multiple comparisons. Fd Technol., 10, 391-392.

MSZ EN ISO (2000): Olajmagdarák. Az olajtartalom meghatározása 1. rész: Hexános (vagy petroléteres) extrakciós módszer. (Oilseed meals. Determination of oil content Part 1: Extraction using hexan (or petrolether).) No. MSZ EN ISO 734-1:2000

MSZ (1988): Lisztvizsgálati módszerek. A vizfelvevőképesség és a sütöipari érték meghatározása. (Methods for flour examinations. Determination of water absorption and industrial quality.) No. MSZ 6369/6-1988

Paraskevopoulou, A., Provatidou, E., Tsotsiou, D. \& Kiosseoglou, V. (2010): Dough rheology and baking performance of wheat flour-lupin protein isolate blends. Fd Res. Int., 43, 1009-1016.

Rodler, I. (2008): Kalória- és tápanyagtáblázat (Calorie and nutritive value tables.) Medicina Kiadó, Budapest. p. 175.

VARGA, L. (2010): Tájékoztató a magyar sütőipar helyzetéröl. (Informant on the situation of Hungarian bakery industry.) Élelmiszeripari aktualitások konferencia. (Conference on Current Topics in the Food Industry.) Budapest, 22th February 2010.

Vidal, A., Marín, S., Ramos, A.J., Cano-Sancho, G. \& Sanchis, V. (2013): Determination of aflatoxins, deoxynivalenol, ochratoxin A and zearalenone in wheat and oat based bran supplements sold in the Spanish market. Fd Chem Toxicol., 53, 133-138. 